\title{
The Interleukin-20 Cytokines in Intestinal Diseases
}

\author{
Jan Hendrik Niess ${ }^{1,2 *}$, Petr Hruz ${ }^{2}$ and Tanay Kaymak ${ }^{1}$ \\ 'Department of Biomedicine, University of Basel, Basel, Switzerland, ${ }^{2}$ Department of Gastroenterology \\ and Hepatology, University Hospital of Basel, Basel, Switzerland
}

OPEN ACCESS

Edited by:

Detlef Neumann, Hannover Medical School,

Germany

Reviewed by:

Christian Michael Hedrich, University of Liverpool,

United Kingdom

Raymond P. Donnelly,

United States Food and Drug Administration, United States

*Correspondence: Jan Hendrik Niess janhendrik.niess@usb.ch

Specialty section: This article was submitted to Cytokines and Soluble Mediators in Immunity, a section of the journal

Frontiers in Immunology

Received: 29 March 2018 Accepted: 04 June 2018

Published: 18 June 2018

Citation:

Niess $J H$, Hruz $P$ and Kaymak $T$ (2018) The Interleukin-20

Cytokines in Intestinal Diseases.

Front. Immunol. 9:1373. doi: 10.3389/fimmu.2018.01373
Autoimmune/inflammatory intestinal diseases, such as Crohn's disease and ulcerative colitis, infectious gastrointestinal diseases, and gastrointestinal cancers, such as colorectal cancer, are worldwide a significant health problem. Intercellular communication and direct contact with the environment as the microbiota colonizes the gastrointestinal surface facilitates these diseases. Cytokines mediate the intercellular communication to maintain the equilibrium between host and environment and to regulate immune responses. One cytokine family that exchange information between immune cells and epithelial cells is the IL-20 cytokine family which includes the cytokines IL-19, IL-20, IL-22, IL-24, and IL-26. These cytokines share common receptor subunits and signaling pathways. IL-22 is the most intensively studied cytokine within this family in contexts of gastrointestinal disease, but the importance of other family members is more and more appreciated. In this review, the potential function of IL-20 cytokines concerning gastrointestinal conditions is discussed.

Keywords: Interleukin-20 family, macrophages, eosinophilic esophagitis, Crohn's disease, ulcerative colitis, colorectal cancer

\section{THE IL-20 CYTOKINE SUBFAMILY WITHIN THE IL-10 CYTOKINE FAMILY}

The IL-20 subfamily that includes the cytokines IL-19, IL-20, IL-22, IL-24, and IL-26, is part of the IL-10 cytokine family, which further includes the cytokines IL-10, IL-28, and IL-29. All members of the IL-10 cytokine family signal through heterodimeric receptors composed of an $\alpha$-chain and $\beta$-chain (Figure 1). Members of the IL-20 cytokine subfamily signal through a receptor that consists of at least one IL-20 receptor (IL-20R) chain. IL-20R $\beta$ can either pair with IL-20R $\alpha$ forming the type I IL-20R, which acts as a receptor for IL-19, IL-20, and IL-24. Furthermore, IL-20R $\beta$ forms with IL-22R $\alpha$ the type II IL-20R through which IL-20 and IL-24 can signal (1). IL-26, which is only present in humans and not in mice, signals through the IL-26 receptor that consists of IL-20R $\alpha$ and IL-10R $\beta$ (2). Moreover, IL-22R $\alpha$ and IL-10R $\beta$ form the IL-22 receptor for IL-22 (1).

The best-characterized cytokine of the IL-20 cytokine family is IL-22 $(3,4)$. IL-22 is produced by $\mathrm{T}$ cells and innate lymphoid cells and induces the production of antimicrobial peptides and mucus by epithelial cells. The other members of the IL-20 subfamily are less characterized concerning their importance in mucosal immunity. Because the expression pattern of IL-20R chains differs between tissues, IL-20 cytokine subfamily members may have different functions in different tissues.

In this review, we will summarize the expression pattern of IL-20Rs in different gastrointestinal tissues and discuss their potential function for intestinal diseases. 
A

$$
\text { 총 }
$$

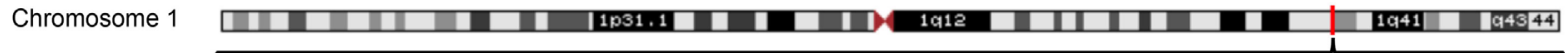

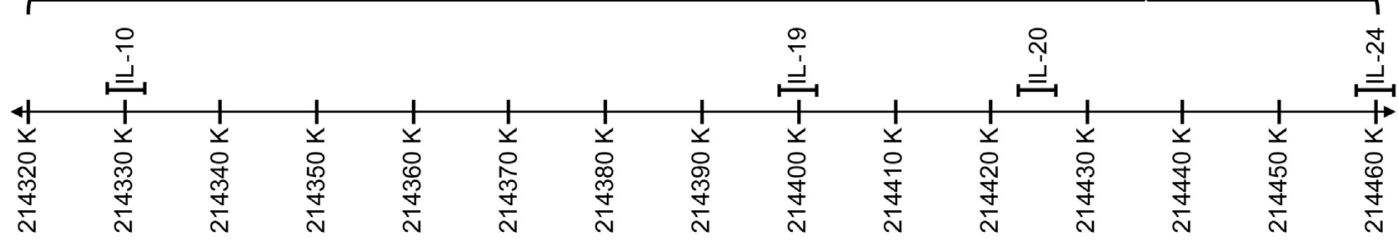

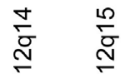

产 立

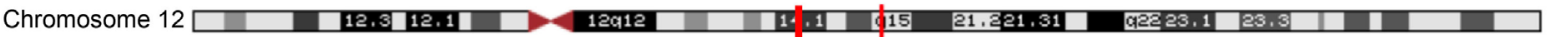

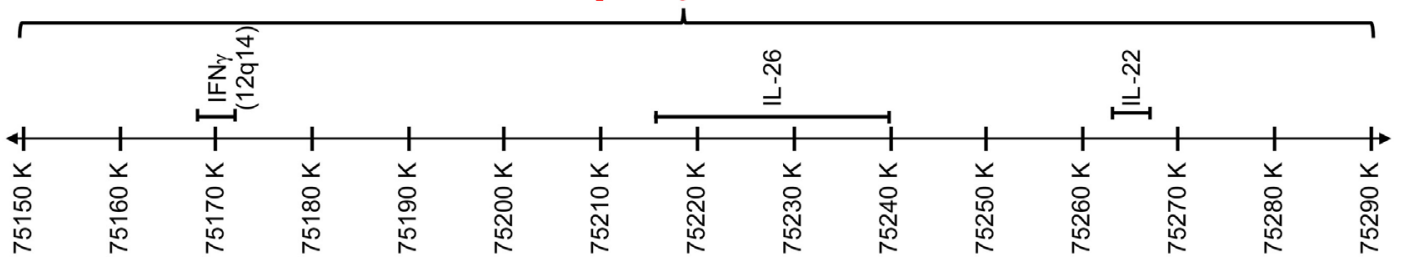

B

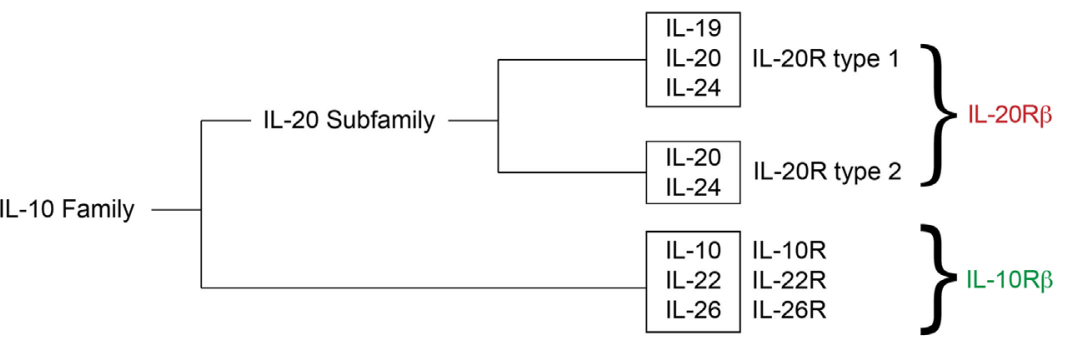

C

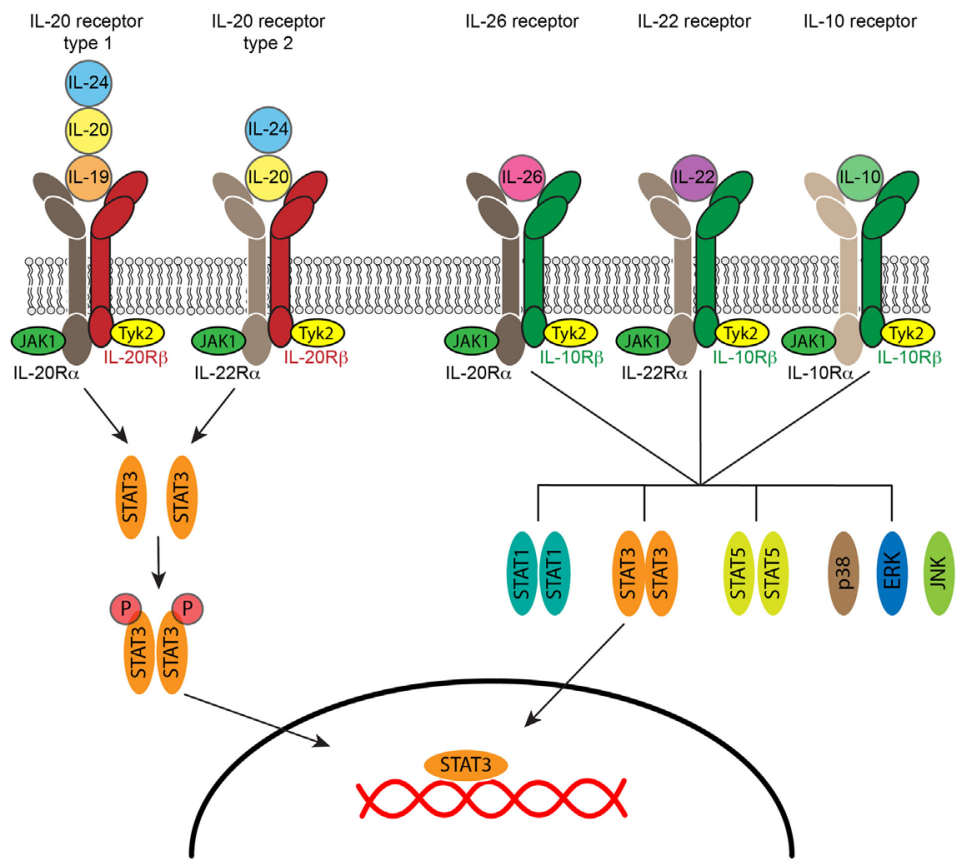

FIGURE 1 | Continued 
FIGURE 1 | The IL-20 cytokines and their receptors. (A) Maps of human chromosome 1 and human chromosome 12 showing close proximity of IL10, IL 19 , I/20, and IL24 on chromosome 1 and IL22, IL26, and IFNG on chromosome 12. Structures of respective chromosomes were retrieved from the NCBI genome viewer. (B) The IL-20 cytokines IL-19, IL-20, and IL-24 cluster in a distinct evolutionary branch within the IL-10. (C) IL-10 receptors are heterodimers consisting of an $\alpha$ and a $\beta$-chain. The IL-20 cytokines IL-19, IL-20, and IL-24 signal through the type I IL-20 receptor (IL-20R); IL-20 and IL-24 but not IL-19 can also signal though the type II IL-20R. The IL-26 receptor, the IL-22 receptor, and the IL-10 receptor have the IL-10R $\beta$-chain in common. IL-10R $\beta$ pairs with IL-20R $\alpha$ to form the IL-26 receptor, with IL-22R $\alpha$ to form the IL-22 receptor, and with IL-10R $\alpha$ to form the IL-10 receptor. Cytokine binding to their receptors leads to an activation of the JAK/STAT pathway [adapted Ref. $(3,4)$ ].

TABLE 1 | Expression of IL-20R $\beta$, IL-20R $\alpha$, and IL-22R $\alpha$ in intestinal tissues, liver, epidermis, and mesenteric lymph nodes, and cellular source of IL-20 family cytokines.

\begin{tabular}{|c|c|c|c|c|c|c|c|c|}
\hline \multirow[b]{2}{*}{ Tissue } & \multicolumn{3}{|c|}{ Receptor subunits } & \multirow[b]{2}{*}{ Cellular source } & \multicolumn{4}{|c|}{ Cytokines } \\
\hline & IL-20R $\beta$ & IL-20R $\alpha$ & IL-22R $\alpha$ & & IL-19 & IL-20 & IL-24 & IL-22 \\
\hline Distal colon & ++ & + & +++ & Monocytes & +++ & +++ & +++ & - \\
\hline Proximal colon & ++ & + & +++ & Macrophages & +++ & +++ & +++ & - \\
\hline Ileum & ++ & - & +++ & Keratinocytes & ++ & ++ & ++ & - \\
\hline Jejunum & ++ & - & +++ & Epithelial cells & ++ & ++ & ++ & - \\
\hline Duodenum & ++ & - & +++ & Fibroblasts & + & + & + & + \\
\hline Glandular stomach & ++ & - & +++ & T cells & - & - & + & +++ \\
\hline Forestomach/esophagus & +++ & ++ & +++ & B cells & + & - & - & - \\
\hline Liver & ++ & - & ++ & NK cells & - & - & - & ++ \\
\hline Mesenteric lymph nodes & ++ & - & + & Innate lymphoid cells type 3 & - & - & - & ++ \\
\hline Epidermis & +++ & +++ & +++ & Dendritic cells & - & + & - & - \\
\hline
\end{tabular}

+++ , very frequent; ++, frequent; +, present; -, not present.

\section{EXPRESSION OF IL-20R ALONG THE GASTROINTESTINAL TRACT}

\section{IL-22 Receptor (IL-22R $\alpha$ + IL-10R $\beta$ )}

IL-22 binds to the IL-22 receptor expressed by intestinal epithelial cells to protect the intestine from damage and to support regeneration by inducing the expression of chemokines involved in cellular mobility, facilitating the expression of the antibacterial lectins RegIII $\beta$ and RegIII $\gamma$ and inducing the expression of mucins after STAT3 activation (5). Therefore, the IL-22 receptor is highly expressed in the entire gastrointestinal tract $(6,7)$ (Table 1).

\section{IL-22 Binding Protein (IL-22bp Also Known as IL-22Ro2)}

Interleukin-22 binding protein is a secreted soluble, monomeric protein that binds IL-22 and competes with IL-22R for IL-22. IL-22bp can hence inhibit the activity of IL-22 (8).

\section{Type I IL-20R (IL-20R $\alpha$ + IL-20R $\beta$ )}

In contrast to the IL-22 receptor, the expression of the type I IL-20R is much lower in the distal and proximal colon of mice $(6,7,9)$. Increased expression of IL-20R $\alpha$, which also signals through STAT3 (10), in colitis models can be explained by infiltration of the inflamed colonic lamina propria with monocytederived macrophages that express IL-20R $\alpha$ (7). IL-20R $\alpha$ is not expressed in the in the small intestine and the glandular stomach (7) but IL-20R $\alpha$ is expressed in the forestomach/esophagus of mice with squamous epithelium and the epidermis (7). Thus, the type I IL-20R is mainly expressed at mucosal surfaced with squamous epithelium.

\section{Type II IL-20R (IL-20R $\beta$ + IL-22R $\alpha$ )}

The type II IL-20R, which signals through STAT3 (10), is expressed in the colon and the small intestine at higher levels than the type I IL-20R but at lower levels than the IL-22 receptor (7). The type I IL-20R serves as a receptor for IL-19, IL-20, and IL-24, while the type II IL-20R is only a receptor for IL-20 and IL-24, but not for IL-19 (3). Signaling through the type I and type II IL-20R may have redundant actions, because different ligands bind to different receptors with different expression patterns of the individual receptor chains. Studies with genetically manipulated mice lacking every single cytokine and each receptor chain are required to delineate this system further.

\section{IL-26 Receptor (IL-20R $\alpha$ + IL-10R $\beta$ )}

The IL-26 receptor, which signals through STAT1 and STAT3, is not expressed in the small intestine and glandular stomach but is present in the esophagus and also in the colon at low levels, but its contribution to diseases of the esophagus and the colon is unknown.

\section{CELLULAR SOURCES OF IL-20 CYTOKINE FAMILY MEMBERS IN THE GASTROINTESTINAL TRACT}

\section{IL-22}

Initially, CD11c + mononuclear phagocytes have been identified as the cellular source of IL-22 (6). Now, type 3 innate lymphoid cells (ILC3) (11), CD4 T cells (12), $\gamma \delta$ T cells (13), and CD1drestricted T cells, such as NKT cells (14) are significant sources of IL-22 in the gastrointestinal tract, where IL-22 contributes to regeneration and host defense. 


\section{IL-19}

Monocytes $(15,16)$, macrophages (17), keratinocytes (18), synovial fibroblasts (19), B cells (20), and airway epithelial cells (21) produce IL-19. In situ hybridization of mouse colonic tissues demonstrated that F4/80 + macrophages and some intestinal epithelial cells produce IL-19 (7). Analysis of an Il19-tdTomato reporter mouse line confirmed that intestinal macrophages produce IL-19 after stimulation with LPS (7), whereas B cells did not produce IL-19 in un-manipulated Il19-tdTomato reporter mice. Because fate-mapping is not possible in this reporter mouse line, the analysis of Il19-tdTomato reporter mice cannot exclude the possibility that a given cell once expressed IL-19 in its history.

\section{IL-20}

Monocytes (16), macrophages (22), keratinocytes (23), and dendritic cells secretes IL-20. Furthermore, IL-1, IL-8, IL-17, and TNF $\alpha$ induce IL-20 expression in keratinocytes (24). In the colon, the expression of IL-20 is low in un-manipulated mice and also during acute dextran Sodium Sulfate (DSS) colitis. Thus, the cellular source of IL-20 in the gut is not well defined.

\section{IL-24}

Monocytes (16), macrophages (25), endothelial cells (16), keratinocytes (23), melanocytes (26), and subepithelial myofibroblasts (27) produce IL-24. In Th2 cells, the transcription factors STAT6 and GATA3 regulate the expression of IL-24 (28). Furthermore, optimal production of IL-24 by macrophages requires type I IFN signaling and co-stimulation through the IL-4/STAT6 pathway, whereas in NK cells optimal IL-24 production requires type I IFNs and STAT4 (29). In IBD patients, colonic subepithelial myofibroblasts produce IL-24 in response to IL- $1 \beta$, IL-17, and LPS (27), but the importance of IL-24 for the development of IBD needs to be further studied.

\section{IL-26}

Th17 cells (30), NK cells (27), fibroblasts (27), and macrophages (27) secrete IL-26. In T cells, IL- $1 \beta$ in combination with IL-23 and presence of low concentration of TGF $\beta$ induces IL-26 expression (31), while in fibroblasts, IL-1 $\beta$ and IL-17 induce IL-26 production. In colonic biopsies from IBD patients, Th17 cells (30), CD56 + NK cells (32), and CD68 + macrophages (32) have been reported to express IL-26. Thus, the cellular target of IL-26 in colonic biopsies is not precisely defined.

\section{IL-20 CYTOKINES HAVE PRO- AND ANTI-INFLAMMATORY EFFECTS}

The IL-20 cytokines IL-19, IL-20, IL-22, IL-24, and IL-26 are elevated in autoimmune/inflammatory diseases, such as in the skin of patients with psoriasis $(18,33,34)$, in synovial fibroblasts, and macrophages of patients with rheumatoid arthritis $(19,35)$ and in patients with inflammatory bowel disease (20, 27, 30, 36-39). Likely, IL-20 cytokines have dual functions as they can exacerbate and attenuate inflammation depending on the tissue contexts by promoting wound healing, tissue protection, and regeneration $(40,41)$. Wound healing, tissue protection, and regeneration depend in part on activated STATs and expression of STAT1/STAT3 responsive genes, such as keratinocyte growth factor and epidermal growth factor $(42,43)$, expression of antiapoptotic genes and mitogenic genes in hepatocytes (44), and protection of intestinal stem cells from apoptosis (45).

\section{IL-20 CYTOKINES IN ESOPHAGEAL DISEASES}

\section{Autoimmune/Inflammatory Diseases}

Although the esophagus can be affected by inflammatory diseases, such as eosinophilic esophagitis (EoE), Crohn's Disease, infectious diseases, or gastroesophageal reflux disease, the mucosal immune system of the esophagus is compared to the small and large intestine rather understudied. EoE, which has been increasingly diagnosed in the last decade, is thought to be a chronic food- and aeroallergen-mediated Th2 disease leading to tissue remodeling with strictures and stenosis (46). The Th2 cytokines IL-4 and IL-13 can induce IL-19 expression in keratinocytes and airway epithelial cells (47). Furthermore, increased expression of IL-19 has been observed in LPS-stimulated macrophages pretreated with IL-4 and IL-13 (48). Nevertheless, the contribution of IL-19, IL-20, and IL-24 in EoE have not been investigated yet.

\section{Infectious Diseases}

IL-22 contributes to the clearance of oropharyngeal Candida infections (49) and is essential for the clearance in individuals and mouse models with an impaired Th1 response, whereas, loss of IL-22 may be compensated in individuals with an intact Th1 response (50). Because IL-26 is only expressed in humans and not in mice, the lack of animal models may in part explain why IL-26 has not been to our knowledge studied yet in contexts of esophageal diseases.

\section{Malignant Diseases of the Esophagus}

Squamous cell carcinoma and adenocarcinoma can develop in the esophagus, but the contribution of IL-20 cytokine family members to the carcinogenesis is mainly unexplored so far. Increased expression of IL-19 and IL-20 in esophageal squamous cell carcinoma has been reported $(22,51)$, but potential mechanisms how members of the IL-20 cytokine family support the development of squamous cell carcinoma and adenocarcinoma in the esophagus is not known yet.

\section{IL-20 CYTOKINES IN GASTRIC DISEASES}

\section{Autoimmune/Inflammatory Diseases}

Autoimmune, chemical induced, and Helicobacter pylori-induced gastritis is the most common inflammatory conditions of the stomach. Contributions of the cytokines IL-19, IL-20, IL-24, and IL-26 for the development of autoimmune gastritis have not been reported yet.

\section{Infectious Gastritis}

Significant increased IL-22 levels have been reported in H. pylori colonized individuals with peptic ulcer disease and gastritis (52). 
Interestingly, $H$. pylori can generate a niche, where $H$. pylori reside, by removing cholesterol from cell membranes and thereby preventing the formation of lipid rafts (53). These lipid rafts are required for the phosphorylation of JAK1, STAT1, and STAT3 in response to IFN $\gamma$ and IL-22 signaling resulting in reduced production of antimicrobial peptides, such as $\beta$-defensin 3 (53). The immunization of $H$. felis with urease/cholera toxin increased IL-22 expression in the gastric mucosa (54). Inhibition of IL-22 with a neutralizing-antibody leads to impaired clearance of $H$. felis suggesting that IL-22 participates in control and clearance of $H$. pylori infections (54). Thus, IL-22 facilitates the clearance of $H$. pylori, but at the same time, $H$. pylori has developed sophisticated pathways by which $H$. pylori deprived itself of effects of IL-22.

\section{Malignant Gastric Diseases}

IL-22 plays a role in host defense against $H$. pylori, a pathogen that supports the development of gastric carcinoma and mucosaassociated lymphoid tissue (MALT) lymphoma. Interestingly, single nucleotide polymorphisms in the IL22 gene increases the risk for the development of MALT lymphoma threefold, but how these genotypes influence IL-22 expression and function is not known (55). Furthermore, IL-22 supports the migration and invasion of gastric cancer cells $(56,57)$. Gastric cancer cells express IL-22Ra and lymphatic invasion and tumor stage (57). Moreover, increased IL-22 producing $T$ cell numbers in the tumor and the peripheral blood is associated with poor outcome $(58,59)$, indicating that IL-22 facilitates progression of gastric cancer.

The IL-20 cytokine IL-24 can induce apoptosis in gastric cancer cells and inhibits tumor angiogenesis in vivo in a chicken embryonic allantois model. Moreover, overexpression of IL-24 in the gastric cancer cell line SGC7901 sensitizes these cells to cisplatin, 5-fluorouracil, adriamycin, and methotrexate (60). By contrast, IL-26 promotes the proliferation of SGC7091 gastric cancer cells by modulating STAT1/STAT3 activation (61). A function of IL-19 and IL-20 in the development of gastric cancer is not reported in the literature so far.

Taken together, this indicates that the relevance of IL-20 cytokines for the development of gastric cancer is not well understood and that members of the IL-20 cytokine family may promote or protect from gastric cancer.

\section{IL-20 CYTOKINES IN INTESTINAL DISEASES}

\section{Inflammatory Bowel Disease}

Although the expression of the type I and type II IL-20R is low in comparison to the IL-22 receptor $(6,9)$, there are some indications that the cytokines IL-19, IL-20, and IL-24 play a role in the pathogenesis of IBD. Increased expression of IL-19, IL-20, and IL-24 has been reported in biopsies of patients with ulcerative colitis and Crohn's disease $(20,27,39)$. In contrast, LPS-stimulated peripheral blood mononuclear cells (PBMCs) from Crohn's patients produced less IL-19 compared to healthy controls (62). Furthermore, IL-19 suppressed the production of TNF $\alpha$ by PBMCs from healthy patients but not by PBMCs from Crohn's disease patients (62). Moreover, single nucleotide polymorphisms in the IL19 gene decrease the susceptibility to ulcerative colitis (63), while changes in the methylation status of the IL19 gene locus have been associated with increased severity of Crohn's disease (64). IL-19 is produced by macrophages, whereas subepithelial myofibroblasts have been identified as a source of IL-24, which induces the production of the mucins (mucin1, mucin3, and mucin4) (27). In colitis models, both accelerated and attenuated DSS colitis has been reported in two different IL-19 KO mouse strains $(7,17)$. Homozygous Il19-tdTomato reporter mice, in which tdTomato replaces exon 3 of the Il19 gene tdTomato, showed attenuated DSS colitis associated with reduced IL-6 production in macrophages (Figure 2). Production of IL-19 by macrophages occurred after a breach of the intestinal barrier with DSS and required an intact bacterial flora because DSS treatment of gnotobiotic animals with a simplified oligomouse microbiota did not induce IL-19 production. IL-19 acts in an autocrine manner on mucosal macrophages, which acquire IL-20R $\alpha$ during their differentiation into tissue macrophages to regulate the production of IL- 6 as colonic macrophages express IL-20R $\alpha$ in contrast to bone marrow-derived macrophages (7).

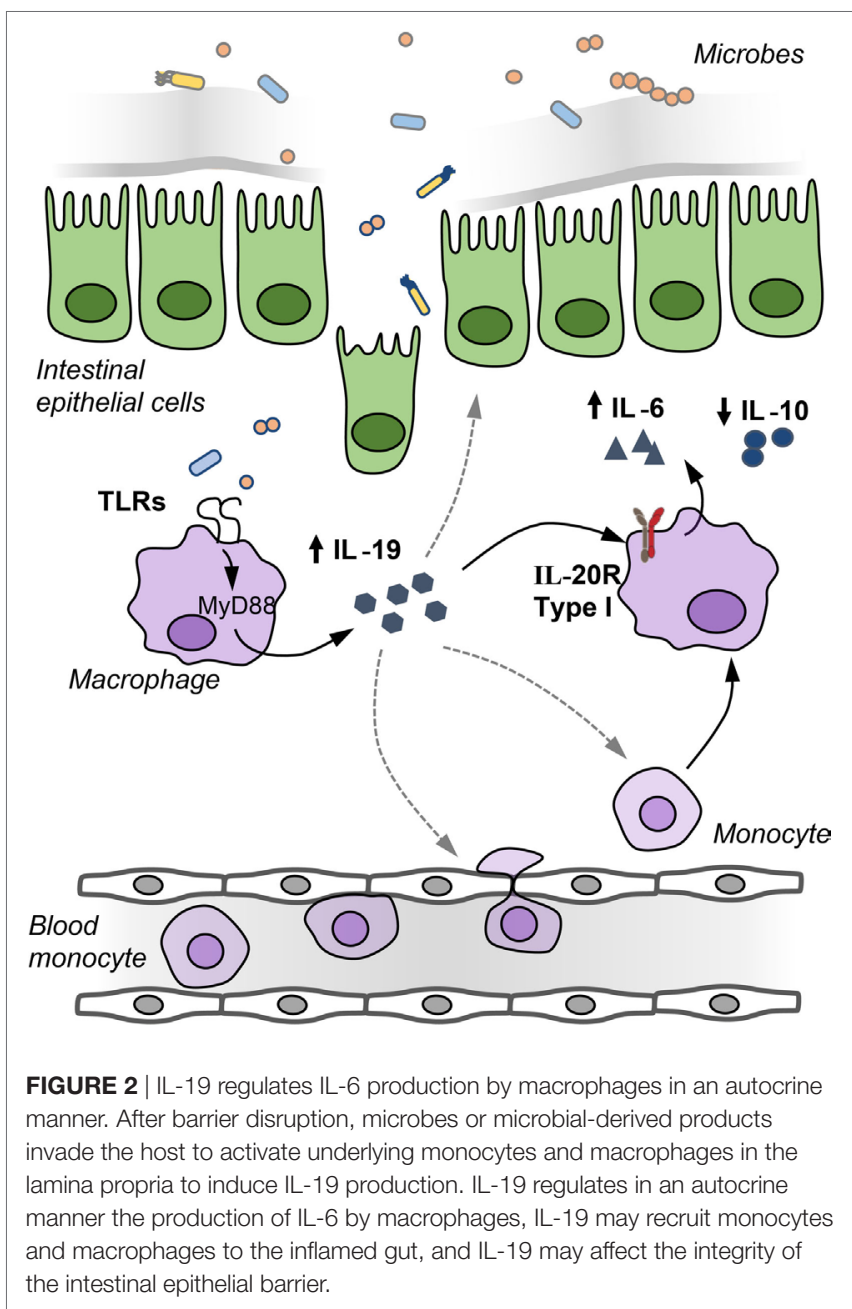


Increased expression of the cytokine IL-26 has been reported in biopsies of Crohn's disease and ulcerative colitis patients $(30,32)$. IL-26 is produced by ROR $\gamma t+$ Th17 cells in the mucosa and binds the IL-26 receptor expressed by subepithelial myofibroblasts and intestinal epithelial cells to induce the expression of the pro-inflammatory cytokines TNF $\alpha$ and IL-8 $(30,32)$. IL-26 is a cationic amphipathic protein that promotes the killing of extracellular bacteria by supporting the formation of membrane-pores and binding to bacterial DNA released from dying bacteria (31). This IL-26/DNA complex shuttles the DNA into myeloid cells, which activates the inflammasome in a STING-dependent manner (65). Interestingly, the translocation of bacterial DNA from the gut into the peripheral blood of Crohn's disease patients leads to increased IL-26 concentrations. Single nucleotide polymorphism in the IL26 gene results in reduced bacterial killing, elevated concentration of pro-inflammatory cytokines, and increased consumption of anti-TNF antibodies in Crohn's disease patients with translocated bacterial DNA (66). Increased IL-26 concentration after translocation of bacterial-derived products from the gut into the host may serve as one line of an innate defense system to protect the host from invaded microbial products.

Elevated IL-22 expression was observed in biopsies of patients with Crohn's disease and ulcerative colitis $(36,37)$. Overexpression of IL-22 in the colon of mice with a local gene delivery led to attenuated colitis associated with STAT3 activation and increased production of mucus-associated proteins by epithelial cells (5). Furthermore, IL-22 promotes wound healing in vitro and in vivo after the damage of the epithelial barrier $(37,67)$. T cells and type 3 innate lymphoid cells produce IL-22 during colitis in response to IL-23 and IL-1 $\beta$ (68). T cells in IBD patients also produce IL-22bp, which can neutralize soluble IL-22. Patients responding to treatment with anti-TNF $\alpha$ antibodies are characterized by reduced IL-22bp, while still producing the tissue-protective cytokine IL-22 (69). Perhaps, differential expression of IL-22bp and IL-22 by T cells in IBD patients receiving anti-TNF $\alpha$ antibodies may in part explain how anti-TNF $\alpha$ antibodies suppress active disease.

In summary, multiple functions of IL-20 cytokines in context of IBD have been described, such as the regulation of IL-6 production by macrophages through IL-19, recognition of bacterial DNA by IL-26, and wound healing by IL-22. However, whether a specific member of the IL-20 cytokine subfamily is a potential target for treatment of IBD requires further studies. These cytokines have pleiotropic functions that can protect from inflammation or facilitate colitis; thus, targeting this cytokine family for the treatment of IBD patients may be a challenge.

\section{INFECTIOUS INTESTINAL DISEASES}

Infection of mice with Citrobacter rodentium leads to increased IL-19, IL-20, and IL-24 expression. C. rodentium serves as a model for infections with attaching and effacing (A/E) bacterial pathogens, such as enteropathogenic Escherichia coli (6). Although C. rodentium infection increased IL-19, IL-20, and IL-24 expression, C. rodentium infected IL-20R $\beta$-deficient animals had comparable survival rates as wild-type animals (6).
However, the injection of a plasmid leading to the overexpression of IL-24 into animals prolonged survival rates after infection with Salmonella typhimurium. IL-24 attracted neutrophils and induced the production of IFN $\gamma$ and IL-12 by neutrophils leading to the activation of CD8 T cells (70). Furthermore, the stimulation of human monocytes with $S$. typhimurium induced the expression of IL-20. When vasoactive intestinal peptide was added to the cultures a 16-fold decrease of IL-20 expression was noted (71), but the relevance of this observation has not been investigated in vivo yet.

Interestingly, IL-19 expression by M-CSF-differentiated bone marrow-derived macrophages was induced by stimulation with the TLR4 ligand LPS, the TLR9 ligand CpG, and the TLR2/6 ligand Pam2CSK4. Stimulation of macrophages with the TLR5 ligand flagellin or the TLR3 ligand poly (I:C) did not induce IL-19 expression, because M-CSF differentiated bone marrow-derived macrophages have a shallow TLR5 expression (7). Because TLR3 signals through TRIF and TLR4, TLR9, and the TLR2/6 require Myd88 for signaling (72), induction of IL-19 depends on Myd88 but not on TRIF. Microbes or their products are, therefore, strong inducers of the IL-20 cytokines.

Pivotal work has demonstrated that IL-22 is essential for the clearance of $C$. rodentium infection in mice. In part, macrophagederived IL-1 $\beta$ and IL-23 facilitate IL-22 production by ILC3 during a $C$. rodentium infection (73-75). Production of IL-22 increases expression of antimicrobial peptides (e.g., RegIII $\beta$ ), production of mucins, and expression of fucosyltransferase 2 required for the fucosylation of epithelial cells (76). Fucosylated proteins are proteins to which the hexose deoxy fucose sugar units are added. Fucosylated proteins are shed into the intestinal lumen, where fucosylated proteins regulate the metabolism of microbes and microbial virulence genes (77). Furthermore, IL-22 regulates the expression of hemopexin, a hemoglobin scavenger, which partially regulates the systemic iron pool and thereby protects from infection (78). Controversially, pathogens are also able to utilize IL-22 to gain an advantage in the process of occupying a niche in the gastrointestinal tract. For example, S. typhimurium induced IL-22 expression leads to the production of the metal-chelating antimicrobial peptides calprotectin and lipocalin-2, which sequester iron. While S. typhimurium can adapt to iron starvation, iron starvation decreases the growth of commensal Enterobacteriaceae supporting an advantage for S. typhimurium (79).

\section{COLORECTAL CANCER}

Because IL-24, which was initially named melanoma differentiation-associated gene-7, suppresses the growth and induces apoptosis of cancer cells (26), the expression of IL-24 in colorectal cancer patients has been determined. In a retrospective study with 96 rectal adenocarcinoma patients, 81 out of 90 patients expressed IL-24. Higher IL-24 expression was reported in well and moderate differentiated carcinomas, and expression of IL-24 negatively correlated with lymph node status as in patients with high IL-24 expression fewer lymph nodes were affected (80). Moreover, the expression of IL-24 was associated with the survival rate of the patients (81). Experimental studies 
with overexpression of IL-24 in cancer cell lines or studies, in which a small molecule stabilizes IL-24, suggested that IL-24 can potentially be used to enhance the efficacy of chemotherapies $(81,82)$.

IL-22 is involved in tissue repair and wound healing. Hernandez and colleagues recently excellently reviewed the importance of IL-22 for the development of colorectal cancer (83). Interestingly, both IL-22bp-deficient animals with elevated IL-22 and IL-22-deficient animals have increased tumor burden in colitis-associated cancer (CAC) model (84). Most likely, IL-22 has anti-inflammatory and antimicrobial effects that protect from cancer, while at the same time IL-22 supports the proliferation of epithelial cells promoting the development of cancer. The IL-20 cytokines IL-19, IL-20, IL-22, IL-24 and IL-26, IL-6, type I interferons, IL-5, and IL-10 signal all through STAT3 downstream of their receptors. Mice that lack STAT3 in epithelial cells develop fewer tumors in a CAC model and even fewer tumors compared to IL-6 deficient mice $(85,86)$. Thus, all individual cytokines that signal through STAT3 may contribute to the development of tumors. It would be interesting to compare tumor development in animals lacking specific IL-20 cytokines or individual receptor chains to STAT3-deficient animals to elucidate the contribution of single members of the IL-20 cytokine family to tumor formation.

\section{CONCLUSION}

The increased interest in the IL-20 cytokine family revealed multiple sources and target cells indicating a wide variety of functions for IL-20 cytokines in the gastrointestinal tract in context of different diseases. The IL-20 cytokines IL-19, IL-20, IL-22, IL-24, and IL-26

\section{REFERENCES}

1. Ouyang W, Rutz S, Crellin NK, Valdez PA, Hymowitz SG. Regulation and functions of the IL-10 family of cytokines in inflammation and disease. Annu Rev Immunol (2011) 29:71-109. doi:10.1146/annurev-immunol-031210101312

2. Sheikh F, Baurin VV, Lewis-Antes A, Shah NK, Smirnov SV, Anantha S, et al. Cutting edge: IL-26 signals through a novel receptor complex composed of IL-20 receptor 1 and IL-10 receptor 2. J Immunol (2004) 172(4):2006-10. doi:10.4049/jimmunol.172.4.2006

3. Wegenka UM. IL-20: biological functions mediated through two types of receptor complexes. Cytokine Growth Factor Rev (2010) 21(5):353-63. doi:10.1016/j.cytogfr.2010.08.001

4. Rutz S, Wang X, Ouyang W. The IL-20 subfamily of cytokines - from host defence to tissue homeostasis. Nat Rev Immunol (2014) 14(12):783-95. doi: $10.1038 /$ nri3766

5. Sugimoto K, Ogawa A, Mizoguchi E, Shimomura Y, Andoh A, Bhan AK, et al. IL-22 ameliorates intestinal inflammation in a mouse model of ulcerative colitis. J Clin Invest (2008) 118(2):534-44. doi:10.1172/JCI33194

6. Zheng Y, Valdez PA, Danilenko DM, Hu Y, Sa SM, Gong Q, et al. Interleukin-22 mediates early host defense against attaching and effacing bacterial pathogens. Nat Med (2008) 14(3):282-9. doi:10.1038/nm1720

7. Steinert A, Linas I, Kaya B, Ibrahim M, Schlitzer A, Hruz P, et al. The stimulation of macrophages with TLR ligands supports increased IL-19 expression in inflammatory bowel disease patients and in colitis models. J Immunol (2017) 199(7):2570-84. doi:10.4049/jimmunol.1700350

8. Kotenko SV, Izotova LS, Mirochnitchenko OV, Esterova E, Dickensheets H, Donnelly RP, et al. Identification, cloning, and characterization of a novel are elevated in patients with IBD, gastrointestinal infections, and gastrointestinal cancers, of which IL-22 is the most intensively studied cytokine of the IL-20 cytokine family in contexts with gastrointestinal diseases by facilitating wound healing, tissue protection, and regeneration. Furthermore, IL-19-deficient animals develop attenuated DSS colitis that is induced by disruption of the epithelial barrier with DSS. Translocated bacterial-derived products induce IL-19 expression, which acts back on macrophages in an autocrine manner to regulate IL- 6 production by macrophages. Future studies with a focus on single members and receptors of the IL-20 cytokine family are required to further understand their relevance for chronic inflammatory diseases, clearance of infectious diseases, and development of cancer in the gastrointestinal tract. Targeting individual members of the IL-20 cytokine family in mice may ultimately pave the way for this cytokine system as a target for therapy of gastrointestinal diseases.

\section{AUTHOR CONTRIBUTIONS}

JHN drafted and wrote the manuscript. $\mathrm{PH}$ reviewed the manuscript and gave suggestions. TK wrote the manuscript and designed the figures.

\section{ACKNOWLEDGMENTS}

This work is supported by the SNSF grant 310030_146290 to JN.

\section{FUNDING}

The funder supported our research but had no influence on the research program. soluble receptor that binds IL-22 and neutralizes its activity. J Immunol (2001) 166(12):7096-103. doi:10.4049/jimmunol.166.12.7096

9. Zenewicz LA, Yancopoulos GD, Valenzuela DM, Murphy AJ, Stevens S, Flavell RA. Innate and adaptive interleukin-22 protects mice from inflammatory bowel disease. Immunity (2008) 29(6):947-57. doi:10.1016/j.immuni.2008.11.003

10. Dumoutier L, Leemans C, Lejeune D, Kotenko SV, Renauld JC. Cutting edge: STAT activation by IL-19, IL-20 and mda-7 through IL-20 receptor complexes of two types. JImmunol (2001) 167(7):3545-9. doi:10.4049/ jimmunol.167.7.3545

11. Satoh-Takayama N, Vosshenrich CA, Lesjean-Pottier S, Sawa S, Lochner M, Rattis F, et al. Microbial flora drives interleukin 22 production in intestinal NKp46+ cells that provide innate mucosal immune defense. Immunity (2008) 29(6):958-70. doi:10.1016/j.immuni.2008.11.001

12. Veldhoen M, Hirota K, Westendorf AM, Buer J, Dumoutier L, Renauld JC, et al. The aryl hydrocarbon receptor links TH17-cell-mediated autoimmunity to environmental toxins. Nature (2008) 453(7191):106-9. doi:10.1038/ nature 06881

13. Martin B, Hirota K, Cua DJ, Stockinger B, Veldhoen M. Interleukin17-producing gammadelta $\mathrm{T}$ cells selectively expand in response to pathogen products and environmental signals. Immunity (2009) 31(2):321-30. doi:10.1016/j.immuni.2009.06.020

14. Goto M, Murakawa M, Kadoshima-Yamaoka K, Tanaka Y, Nagahira K, Fukuda Y, et al. Murine NKT cells produce Th17 cytokine interleukin-22. Cell Immunol (2009) 254(2):81-4. doi:10.1016/j.cellimm.2008.10.002

15. Gallagher G, Dickensheets H, Eskdale J, Izotova LS, Mirochnitchenko OV, Peat JD, et al. Cloning, expression and initial characterization of interleukin-19 (IL-19), a novel homologue of human interleukin-10 (IL-10). Genes Immun (2000) 1(7):442-50. doi:10.1038/sj.gene.6363714 
16. Wolk K, Kunz S, Asadullah K, Sabat R. Cutting edge: immune cells as sources and targets of the IL-10 family members? J Immunol (2002) 168(11):5397-402. doi:10.4049/jimmunol.168.11.5397

17. Azuma YT, Matsuo Y, Kuwamura M, Yancopoulos GD, Valenzuela DM, Murphy AJ, et al. Interleukin-19 protects mice from innate-mediated colonic inflammation. Inflamm Bowel Dis (2010) 16(6):1017-28. doi:10.1002/ ibd. 21151

18. Romer J, Hasselager E, Norby PL, Steiniche T, Thorn Clausen J, Kragballe K. Epidermal overexpression of interleukin-19 and -20 mRNA in psoriatic skin disappears after short-term treatment with cyclosporine a or calcipotriol. J Invest Dermatol (2003) 121(6):1306-11. doi:10.1111/j.1523-1747. 2003.12626.x

19. Sakurai N, Kuroiwa T, Ikeuchi H, Hiramatsu N, Maeshima A, Kaneko Y, et al. Expression of IL-19 and its receptors in RA: potential role for synovial hyperplasia formation. Rheumatology (Oxford) (2008) 47(6):815-20. doi:10.1093/rheumatology/ken061

20. Fonseca-Camarillo G, Furuzawa-Carballeda J, Granados J, YamamotoFurusho JK. Expression of interleukin (IL)-19 and IL-24 in inflammatory bowel disease patients: a cross-sectional study. Clin Exp Immunol (2014) 177(1):64-75. doi:10.1111/cei.12285

21. Zhong H, Wu Y, Belardinelli L, Zeng D. A2B adenosine receptors induce IL-19 from bronchial epithelial cells, resulting in TNF-alpha increase. Am J Respir Cell Mol Biol (2006) 35(5):587-92. doi:10.1165/rcmb.2005-0476OC

22. Hsing CH, Ho CL, Chang LY, Lee YL, Chuang SS, Chang MS. Tissue microarray analysis of interleukin-20 expression. Cytokine (2006) 35(1-2):44-52. doi:10.1016/j.cyto.2006.07.006

23. Kunz S, Wolk K, Witte E, Witte K, Doecke WD, Volk HD, et al. Interleukin (IL)-19, IL-20 and IL-24 are produced by and act on keratinocytes and are distinct from classical ILs. Exp Dermatol (2006) 15(12):991-1004. doi:10.1111/j.1600-0625.2006.00516.x

24. Wolk K, Witte E, Warszawska K, Schulze-Tanzil G, Witte K, Philipp S, et al. The Th17 cytokine IL-22 induces IL-20 production in keratinocytes: a novel immunological cascade with potential relevance in psoriasis. Eur J Immunol (2009) 39(12):3570-81. doi:10.1002/eji.200939687

25. Garn H, Schmidt A, Grau V, Stumpf S, Kaufmann A, Becker M, et al. IL-24 is expressed by rat and human macrophages. Immunobiology (2002) 205 (3):321-34. doi:10.1078/0171-2985-00135

26. Jiang H, Lin JJ, Su ZZ, Goldstein NI, Fisher PB. Subtraction hybridization identifies a novel melanoma differentiation associated gene, mda-7, modulated during human melanoma differentiation, growth and progression. Oncogene (1995) 11(12):2477-86.

27. Andoh A, Shioya M, Nishida A, Bamba S, Tsujikawa T, Kim-Mitsuyama S, et al. Expression of IL-24, an activator of the JAK1/STAT3/SOCS3 cascade, is enhanced in inflammatory bowel disease. J Immunol (2009) 183(1):687-95. doi:10.4049/jimmunol.0804169

28. Stevens L, Htut TM, White D, Li X, Hanidu A, Stearns C, et al. Involvement of GATA3 in protein kinase $\mathrm{C}$ theta-induced Th2 cytokine expression. Eur J Immunol (2006) 36(12):3305-14. doi:10.1002/eji.200636400

29. Dabitao D, Hedrich CM, Wang F, Vacharathit V, Bream JH. Cell-specific requirements for STAT proteins and type I IFN receptor signaling discretely regulate IL-24 and IL-10 expression in NK cells and macrophages. J Immunol (2018) 200(6):2154-64. doi:10.4049/jimmunol.1701340

30. Dambacher J, Beigel F, Zitzmann K, De Toni EN, Goke B, Diepolder HM, et al. The role of the novel Th17 cytokine IL-26 in intestinal inflammation. Gut (2009) 58(9):1207-17. doi:10.1136/gut.2007.130112

31. Meller S, Di Domizio J, Voo KS, Friedrich HC, Chamilos G, Ganguly D, et al. $\mathrm{T}(\mathrm{H}) 17$ cells promote microbial killing and innate immune sensing of DNA via interleukin 26. Nat Immunol (2015) 16(9):970-9. doi:10.1038/ni.3211

32. Fujii M, Nishida A, Imaeda H, Ohno M, Nishino K, Sakai S, et al. Expression of interleukin-26 is upregulated in inflammatory bowel disease. World J Gastroenterol (2017) 23(30):5519-29. doi:10.3748/wjg.v23.i30.5519

33. Wolk K, Kunz S, Witte E, Friedrich M, Asadullah K, Sabat R. IL-22 increases the innate immunity of tissues. Immunity (2004) 21(2):241-54. doi:10.1016/j. immuni.2004.07.007

34. Otkjaer K, Kragballe K, Funding AT, Clausen JT, Noerby PL, Steiniche T, et al. The dynamics of gene expression of interleukin-19 and interleukin-20 and their receptors in psoriasis. Br J Dermatol (2005) 153(5):911-8. doi:10.1111/j.1365-2133.2005.06800.x
35. Ikeuchi H, Kuroiwa T, Hiramatsu N, Kaneko Y, Hiromura K, Ueki K, et al. Expression of interleukin-22 in rheumatoid arthritis: potential role as a proinflammatory cytokine. Arthritis Rheum (2005) 52(4):1037-46. doi:10.1002/ art. 20965

36. Andoh A, Zhang Z, Inatomi O, Fujino S, Deguchi Y, Araki Y, et al. Interleukin-22, a member of the IL-10 subfamily, induces inflammatory responses in colonic subepithelial myofibroblasts. Gastroenterology (2005) 129(3):969-84. doi:10.1053/j.gastro.2005.06.071

37. Brand S, Beigel F, Olszak T, Zitzmann K, Eichhorst ST, Otte JM, et al. IL-22 is increased in active Crohn's disease and promotes proinflammatory gene expression and intestinal epithelial cell migration. Am J Physiol Gastrointest Liver Physiol (2006) 290(4):G827-38. doi:10.1152/ajpgi.00513.2005

38. Corvaisier M, Delneste Y, Jeanvoine H, Preisser L, Blanchard S, Garo E, et al. IL-26 is overexpressed in rheumatoid arthritis and induces proinflammatory cytokine production and Th17 cell generation. PLoS Biol (2012) 10(9):e1001395. doi:10.1371/journal.pbio.1001395

39. Fonseca-Camarillo G, Furuzawa-Carballeda J, Llorente L, Yamamoto-Furusho JK. IL-10 - and IL-20 - expressing epithelial and inflammatory cells are increased in patients with ulcerative colitis. J Clin Immunol (2013) 33(3):640-8. doi:10.1007/ s10875-012-9843-4

40. Laurence A, O'Shea JJ, Watford WT. Interleukin-22: a sheep in wolf's clothing. Nat Med (2008) 14(3):247-9. doi:10.1038/nm0308-247

41. Seiderer J, Brand S. IL-22: a two-headed cytokine in IBD? Inflamm Bowel Dis (2009) 15(3):473-4. doi:10.1002/ibd.20625

42. Sa SM, Valdez PA, Wu J, Jung K, Zhong F, Hall L, et al. The effects of IL-20 subfamily cytokines on reconstituted human epidermis suggest potential roles in cutaneous innate defense and pathogenic adaptive immunity in psoriasis. J Immunol (2007) 178(4):2229-40. doi:10.4049/jimmunol.178.11. 7487-a

43. Sun DP, Yeh CH, So E, Wang LY, Wei TS, Chang MS, et al. Interleukin (IL)-19 promoted skin wound healing by increasing fibroblast keratinocyte growth factor expression. Cytokine (2013) 62(3):360-8. doi:10.1016/j.cyto. 2013.03.017

44. Radaeva S, Sun R, Pan HN, Hong F, Gao B. Interleukin 22 (IL-22) plays a protective role in T cell-mediated murine hepatitis: IL-22 is a survival factor for hepatocytes via STAT3 activation. Hepatology (2004) 39(5):1332-42. doi:10.1002/hep.20184

45. Hanash AM, Dudakov JA, Hua G, O’Connor MH, Young LF, Singer NV, et al. Interleukin-22 protects intestinal stem cells from immune-mediated tissue damage and regulates sensitivity to graft versus host disease. Immunity (2012) 37(2):339-50. doi:10.1016/j.immuni.2012.05.028

46. Straumann A. The natural history and complications of eosinophilic esophagitis. Thorac Surg Clin (2011) 21(4):575-87. doi:10.1016/j.thorsurg.2011. 09.004

47. Bao L, Alexander JB, Shi VY, Mohan GC, Chan LS. Interleukin-4 upregulation of epidermal interleukin-19 expression in keratinocytes involves the binding of signal transducer and activator of transcription 6 (Stat6) to the imperfect Stat6 sites. Immunology (2014) 143(4):601-8. doi:10.1111/ imm.12339

48. El Chartouni C, Benner C, Eigner M, Lichtinger M, Rehli M. Transcriptional effects of colony-stimulating factor-1 in mouse macrophages. Immunobiology (2010) 215(6):466-74. doi:10.1016/j.imbio.2009.08.002

49. Bichele R, Karner J, Truusalu K, Smidt I, Mandar R, Conti HR, et al. IL-22 neutralizing autoantibodies impair fungal clearance in murine oropharyngeal candidiasis model. Eur J Immunol (2018) 48(3):464-70. doi:10.1002/ eji.201747209

50. Conti HR, Shen F, Nayyar N, Stocum E, Sun JN, Lindemann MJ, et al. Th17 cells and IL-17 receptor signaling are essential for mucosal host defense against oral candidiasis. J Exp Med (2009) 206(2):299-311. doi:10.1084/jem. 20081463

51. Hsing CH, Kwok FA, Cheng HC, Li CF, Chang MS. Inhibiting interleukin-19 activity ameliorates esophageal squamous cell carcinoma progression. PLoS One (2013) 8(10):e75254. doi:10.1371/journal.pone.0075254

52. Zhuang Y, Cheng P, Liu XF, Peng LS, Li BS, Wang TT, et al. A proinflammatory role for Th22 cells in Helicobacter pylori-associated gastritis. Gut (2015) 64(9):1368-78. doi:10.1136/gutjnl-2014-307020

53. Morey P, Pfannkuch L, Pang E, Boccellato F, Sigal M, Imai-Matsushima A, et al. Helicobacter pylori depletes cholesterol in gastric glands to prevent interferon 
gamma signaling and escape the inflammatory response. Gastroenterology (2018) 154(5):1391-1404.e9. doi:10.1053/j.gastro.2017.12.008

54. Moyat M, Bouzourene H, Ouyang W, Iovanna J, Renauld JC, Velin D. IL-22induced antimicrobial peptides are key determinants of mucosal vaccineinduced protection against $H$. pylori in mice. Mucosal Immunol (2017) 10(1): 271-81. doi:10.1038/mi.2016.38

55. Liao F, Hsu YC, Kuo SH, Yang YC, Chen JP, Hsu PN, et al. Genetic polymorphisms and tissue expression of interleukin-22 associated with risk and therapeutic response of gastric mucosa-associated lymphoid tissue lymphoma. Blood Cancer J (2014) 4:eXX. doi:10.1038/bcj.2014.70

56. Fukui H, Zhang X, Sun C, Hara K, Kikuchi S, Yamasaki T, et al. IL-22 produced by cancer-associated fibroblasts promotes gastric cancer cell invasion via STAT3 and ERK signaling. Br J Cancer (2014) 111(4):763-71. doi:10.1038/ bjc.2014.336

57. Ji Y, Yang X, Li J, Lu Z, Li X, Yu J, et al. IL-22 promotes the migration and invasion of gastric cancer cells via IL-22R1/AKT/MMP-9 signaling. Int J Clin Exp Pathol (2014) 7(7):3694-703.

58. Liu T, Peng L, Yu P, Zhao Y, Shi Y, Mao X, et al. Increased circulating Th22 and Th17 cells are associated with tumor progression and patient survival in human gastric cancer. J Clin Immunol (2012) 32(6):1332-9. doi:10.1007/ s10875-012-9718-8

59. Zhuang Y, Peng LS, Zhao YL, Shi Y, Mao XH, Guo G, et al. Increased intratumoral IL-22-producing CD4(+) T cells and Th22 cells correlate with gastric cancer progression and predict poor patient survival. Cancer Immunol Immunother (2012) 61(11):1965-75. doi:10.1007/s00262-012-1241-5

60. Mao Z, Bian G, Sheng W, He S, Yang J, Dong X. Adenovirus-mediated IL-24 expression enhances the chemosensitivity of multidrug-resistantgastric cancer cells to cisplatin. Oncol Rep (2013) 30(5):2288-96. doi:10.3892/or. 2013.2695

61. You W, Tang Q, Zhang C, Wu J, Gu C, Wu Z, et al. IL-26 promotes the proliferation and survival of human gastric cancer cells by regulating the balance of STAT1 and STAT3 activation. PLoS One (2013) 8(5):e63588. doi:10.1371/ journal.pone. 0063588

62. Canto E, Garcia Planella E, Zamora-Atenza C, Nieto JC, Gordillo J, Ortiz MA, et al. Interleukin-19 impairment in active Crohn's disease patients. PLoS One (2014) 9(4):e93910. doi:10.1371/journal.pone.0093910

63. Yamamoto-Furusho JK, Alvarez-Leon E, Fragoso JM, Gozalishvilli A, Vallejo M, Vargas-Alarcon G. Protective role of interleukin-19 gene polymorphisms in patients with ulcerative colitis. Hum Immunol (2011) 72(11):1029-32. doi:10.1016/j.humimm.2011.08.013

64. Nimmo ER, Prendergast JG, Aldhous MC, Kennedy NA, Henderson P, Drummond HE, et al. Genome-wide methylation profiling in Crohn's disease identifies altered epigenetic regulation of key host defense mechanisms including the Th17 pathway. Inflamm Bowel Dis (2012) 18(5):889-99. doi:10.1002/ ibd. 21912

65. Poli C, Augusto JF, Dauve J, Adam C, Preisser L, Larochette V, et al. IL-26 confers proinflammatory properties to extracellular DNA. J Immunol (2017) 198(9):3650-61. doi:10.4049/jimmunol.1600594

66. Pinero P, Juanola O, Gutierrez A, Zapater P, Gimenez P, Steinert A, et al. IL26 modulates cytokine response and anti-TNF consumption in Crohn's disease patients with bacterial DNA. J Mol Med (Berl) (2017) 95(11):1227-36. doi:10.1007/s00109-017-1585-6

67. Pickert G, Neufert C, Leppkes M, Zheng Y, Wittkopf N, Warntjen M, et al. STAT3 links IL-22 signaling in intestinal epithelial cells to mucosal wound healing. J Exp Med (2009) 206(7):1465-72. doi:10.1084/jem.20082683

68. Sonnenberg GF, Fouser LA, Artis D. Border patrol: regulation of immunity, inflammation and tissue homeostasis at barrier surfaces by IL-22. Nat Immunol (2011) 12(5):383-90. doi:10.1038/ni.2025

69. Pelczar P, Witkowski M, Perez LG, Kempski J, Hammel AG, Brockmann L, et al. A pathogenic role for T cell-derived IL-22BP in inflammatory bowel disease. Science (2016) 354(6310):358-62. doi:10.1126/science.aah5903

70. Ma Y, Chen H, Wang Q, Luo F, Yan J, Zhang XL. IL-24 protects against Salmonella typhimurium infection by stimulating early neutrophil Th1 cytokine production, which in turn activates CD8+ T cells. Eur J Immunol (2009) 39(12):3357-68. doi:10.1002/eji.200939678

71. Ibrahim H, Askar B, Barrow P, Foster N. Dysregulation of JAK/STAT genes by vasoactive intestinal peptide (VIP) in Salmonella-infected monocytes may inhibit its therapeutic potential in human sepsis. Cytokine (2018) 105:49-56. doi:10.1016/j.cyto.2018.02.014

72. Cario E. Toll-like receptors in inflammatory bowel diseases: a decade later. Inflamm Bowel Dis (2010) 16(9):1583-97. doi:10.1002/ibd.21282

73. Manta C, Heupel E, Radulovic K, Rossini V, Garbi N, Riedel CU, et al. CX(3)CR1(+) macrophages support IL-22 production by innate lymphoid cells during infection with Citrobacter rodentium. Mucosal Immunol (2013) 6(1):177-88. doi:10.1038/mi.2012.61

74. Longman RS, Diehl GE, Victorio DA, Huh JR, Galan C, Miraldi ER, et al. CX(3)CR1(+) mononuclear phagocytes support colitis-associated innate lymphoid cell production of IL-22. JExp Med (2014) 211(8):1571-83. doi:10.1084/jem.20140678

75. Seo SU, Kuffa P, Kitamoto S, Nagao-Kitamoto H, Rousseau J, Kim YG, et al. Intestinal macrophages arising from CCR2(+) monocytes control pathogen infection by activating innate lymphoid cells. Nat Commun (2015) 6:8010. doi:10.1038/ncomms 9010

76. Pham TA, Clare S, Goulding D, Arasteh JM, Stares MD, Browne HP, et al. Epithelial IL-22RA1-mediated fucosylation promotes intestinal colonization resistance to an opportunistic pathogen. Cell Host Microbe (2014) 16(4): 504-16. doi:10.1016/j.chom.2014.08.017

77. Pickard JM, Maurice CF, Kinnebrew MA, Abt MC, Schenten D, Golovkina TV, et al. Rapid fucosylation of intestinal epithelium sustains host-commensal symbiosis in sickness. Nature (2014) 514(7524):638-41. doi:10.1038/ nature 13823

78. Sakamoto K, Kim YG, Hara H, Kamada N, Caballero-Flores G, Tolosano E, et al. IL-22 controls iron-dependent nutritional immunity against systemic bacterial infections. Sci Immunol (2017) 2(8). doi:10.1126/sciimmunol. aai8371

79. Behnsen J, Jellbauer S, Wong CP, Edwards RA, George MD, Ouyang W, et al. The cytokine IL-22 promotes pathogen colonization by suppressing related commensal bacteria. Immunity (2014) 40(2):262-73. doi:10.1016/j. immuni.2014.01.003

80. Choi Y, Roh MS, Hong YS, Lee HS, Hur WJ. Interleukin-24 is correlated with differentiation and lymph node numbers in rectal cancer. World J Gastroenterol (2011) 17(9):1167-73. doi:10.3748/wjg.v17.i9.1167

81. Xu S, Oshima T, Imada T, Masuda M, Debnath B, Grande F, et al. Stabilization of MDA-7/IL-24 for colon cancer therapy. Cancer Lett (2013) 335(2): 421-30. doi:10.1016/j.canlet.2013.02.055

82. Lebedeva IV, Su ZZ, Emdad L, Kolomeyer A, Sarkar D, Kitada S, et al. Targeting inhibition of K-ras enhances Ad.mda-7-induced growth suppression and apoptosis in mutant K-ras colorectal cancer cells. Oncogene (2007) 26(5):733-44. doi:10.1038/sj.onc.1209813

83. Hernandez P, Gronke K, Diefenbach A. A catch-22: interleukin-22 and cancer. Eur J Immunol (2018) 48(1):15-31. doi:10.1002/eji.201747183

84. Huber S, Gagliani N, Zenewicz LA, Huber FJ, Bosurgi L, Hu B, et al. IL-22BP is regulated by the inflammasome and modulates tumorigenesis in the intestine. Nature (2012) 491(7423):259-63. doi:10.1038/nature11535

85. Bollrath J, Phesse TJ, von Burstin VA, Putoczki T, Bennecke M, Bateman T, et al. gp130-mediated Stat3 activation in enterocytes regulates cell survival and cell-cycle progression during colitis-associated tumorigenesis. Cancer Cell (2009) 15(2):91-102. doi:10.1016/j.ccr.2009.01.002

86. Grivennikov S, Karin E, Terzic J, Mucida D, Yu GY, Vallabhapurapu S, et al. IL-6 and Stat 3 are required for survival of intestinal epithelial cells and development of colitis-associated cancer. Cancer Cell (2009) 15(2):103-13. doi:10.1016/j.ccr.2009.01.001

Conflict of Interest Statement: The authors declare that the research was conducted in the absence of any commercial or financial relationships that could be construed as a potential conflict of interest.

Copyright $\odot 2018$ Niess, Hruz and Kaymak. This is an open-access article distributed under the terms of the Creative Commons Attribution License (CC BY). The use, distribution or reproduction in other forums is permitted, provided the original author(s) and the copyright owner are credited and that the original publication in this journal is cited, in accordance with accepted academic practice. No use, distribution or reproduction is permitted which does not comply with these terms. 